\title{
Realidade e representação no romance regionalista brasileiro: tradição e atualidade
}

Juliana Santini Universidade Estadual Paulista

Resumo: Este trabalho apresenta uma discussão em torno do romance regionalista na história da literatura brasileira e sua relação com a representação do real. Sob essa perspectiva, analisa-se de que modo o romance Galileia, de Ronaldo Correia de Brito, retoma, atualiza ou recusa, na prosa contemporânea, aspectos que determinaram esse tipo de produção ao longo da diacronia literária brasileira.

Palavras-chave: Romance regionalista, Representação, Narrativa contemporânea.

A proposição de que o romance regionalista articula a linguagem à representação da realidade encontra antecedentes nas reflexões que, ao longo do Romantismo, debateram a legitimidade das formas da nação que se fundavam no

1 Parte desta reflexão foi apresentada no XIII Congresso Internacional da ABRALIC, em mesa-redonda intitulada "Regionalismo na Literatura Brasileira". 
texto literário em meados do século XIX. A carta que Franklin Távora escreve a José de Alencar em 1876, prefácio do romance O cabeleira - que posteriormente ficaria conhecida sob o título "Uma literatura do Norte" - muito revela sobre um projeto literário afinado ao interesse de transformar um determinado registro do real em matéria da ficção: "[...] todo o Norte enfim, se Deus ajudar, virá a figurar nestes escritos, que não se destinam a alcançar outro fim senão mostrar aos que não a conhecem, ou por falso juízo a desprezam, a rica mina das tradições e crônicas das nossas províncias setentrionais".

O desejo expresso por Franklin Távora baseia-se no deslocamento do eixo de representação da prosa de ficção para o norte do país, tendo como base a ideia de que, por estar afastada do litoral e, portanto, mais distante da influência transformadora do colonizador, a região conteria elementos mais genuínos, que poderiam subsidiar a forma romanesca em seu instinto de nacionalidade. A origem do romance regionalista no Brasil liga-se à tentativa de dar forma a esse desejo de construir uma imagem da nação a partir do trato com o dado local que, nesse momento, longe ainda da consciência da diversidade regional, aparece como epítome de uma nação nova, grandiosa, que quer firmar sua independência no campo da política e da literatura. É no bojo dessa "consciência de país novo" que, no princípio, o texto regionalista estará colado, em sua fatura, a um conteúdo exterior, por meio da idealização e do exotismo românticos.

É fato que, no projeto romântico, essa ligação a um real observável não carrega consigo o interesse de construir uma observação crítica e profunda da sociedade ou dos indivíduos que a compõem. Antes, sujeito e sociedade aparecem como elementos cuja harmonia seria determinada pela intenção de tornar o primeiro forte e a segunda, exuberante. Nesse ponto baseia-se o conhecido desabafo de Machado de Assis, publicado no jornal New World, em Nova Iorque, opondo-se ao romance romântico inclinado à representação do dado peculiar: "Do romance puramente de análise, raríssimo exemplar temos, ou porque nossa índole não nos chame para aí, ou porque seja esta casta de obras ainda incompatível com nossa adolescência literária”.

Publicado três anos antes do prefácio de Franklin Távora, o ensaio "Notícia da atual literatura brasileira - Instinto de nacionalidade", de Machado

2 TÁVORA. O cabeleira, p. 18.

3 CANDIDO. Literatura e subdesenvolvimento, p. 146.

4 ASSIS. Obras completas, v. III, p. 137. 
de Assis, deixa antever justamente o que, no seio do indianismo romântico, estaria na gênese da literatura regionalista brasileira, marcada, em grande parte, pelo dado exterior que, incorporado pela narrativa, sofreria um processo de mediação, vetor do exotismo particularizador dessa literatura. O que Machado reivindicava para o romance do século XIX era justamente a desvinculação do dado individualizante e enaltecedor ou, no limite, a incorporação de um olhar crítico, capaz de estabelecer uma nova relação com o dado referencial. Nesse sentido, o romance indianista romântico e seu desdobramento regionalista não conseguem atingir justamente o que, de modo geral, definiria o Realismo no século XIX e, particularmente, a prosa machadiana, já que "[...] o processo mimético efetivado pelo realismo não é de dimensão apenas referencial, descritiva, fotográfica; trata-se de imitação em profundidade, cuja dimensão conotativa está inextricavelmente ligada à história e à sociedade".5

As três últimas décadas do século XIX e mesmo as primeiras do século XX assistiram, ao lado da ficção urbana e da poesia, ao desenvolvimento da narrativa regionalista que, desvinculando-se ora mais, ora menos do projeto ideológico romântico, fará do conto sertanejo seu principal espaço de trabalho. O caráter essencialmente descritivo dessa literatura não apenas motivará Antonio Candido a generalizar toda essa produção e a reduzi-la ao caráter de prosa pitoresca, mas também a enfatizar uma suposta artificialidade na incorporação do real pela ficção. Menos do que simplesmente discordar da acidez com que Candido aborda a questão em $1972^{6}$, interessa perceber que o conto sertanejo pré-modernista insere-se historicamente no movimento dialético que caracteriza a literatura brasileira e sua oscilação entre afirmação nacional e transplantação.

Esse posicionamento institui uma dinâmica no desenvolvimento da ficção regionalista brasileira, que teria sua base fundamentadora inicial não mais na transposição do Romantismo para o Realismo, mas em um fator de ordem sócio-ideológica que, antes, determinaria a produção regional como um ramo do nacionalismo literário, acompanhando um processo de euforia e, depois, de descrença em relação à prosperidade do país. É desse modo que o conto regionalista concretiza a proposta de uma representação em que a narrativa liga-se ao real com o intento de incorporar esteticamente uma realidade, por assim dizer, periférica, distante da Corte e, posteriormente, do polo de irradiação

5 PELLEGRINI. Realismo: postura e método, p. 145. Grifo do autor.

6 Cf. CANDIDO. A literatura e a formação do homem. 
de civilização e urbanidade: "há que se ressaltar [...] que Simões Lopes Neto e Afonso Arinos localizaram o veio do regionalismo: observaram, com acuidade e realismo, tipos, costumes e paisagens regionais". ${ }^{7}$

Entre o conto sertanejo - que fará Antonio Candido, no conjunto de sua obra, recusar o regionalismo de fins do século XIX justamente pelo tipo de relação estabelecida com a realidade referencial - e o romance de 30 do século XX colocam-se todo o primeiro Modernismo no Brasil e seu diálogo direto com as vanguardas. É fato que a Semana de Arte Moderna representou uma guinada na literatura e nas artes plásticas brasileiras, especialmente no modo de avaliação do dado local, tomado, sobretudo, como meio de recuperação de um passado a ser redescoberto pelo olhar modernista, erigindo a tradição sob os traços da novidade da forma ${ }^{8}$, que foge da figuratividade plástica e da rigidez da linguagem literária. Por outro lado, essa proposta estética do grupo modernista inicial não encontrou resposta unânime nas diferentes regiões do país e permaneceu atrelada à esfera do desenvolvimento econômico e cultural de São Paulo e Rio de Janeiro, o que impulsionou a reação do grupo nordestino reunido em torno do pensamento de Gilberto Freyre, no Centro Regionalista do Nordeste, a partir de 1926.

Subjaz à visão de diversidade cultural, fundamentadora do "Manifesto regionalista", a mesma concepção federalista de um território nacional retalhado em regiões a serem representadas esteticamente que influenciou parte da literatura produzida ao longo do Pré-Modernismo. Ter-se-ia, portanto, um projeto artístico-cultural descentralizador, valorizador dos elementos caracterizadores das particularidades da região Nordeste, embora fique clara no manifesto do grupo a defesa da expansão desse trabalho para outras áreas do país. O fato é que o Grupo Regionalista do Nordeste, embora sem grande repercussão na imprensa da época, apresentava uma contraface do Modernismo heroico de 22 ao colocar em cena uma realidade diversa daquela que fomentara o movimento modernista em um espaço geográfico que se reconhecia como edificado sob o signo da modernidade: a criação do Centro Regionalista do Nordeste marca, portanto, a tentativa de quebra da hegemonia cultural do eixo Rio-São Paulo, fixando hábitos e tradições responsáveis pela definição do homem nordestino e pelo lugar que lhe era dado na esfera social.

7 MARCHEZAN. Introdução, p. X.

8 Cf. SANTIAGO. A permanência do discurso da tradição no Modernismo, p. 110. 
É justamente essa perspectiva ideológica, ligada a um projeto estético, que fez do romance o suporte de uma observação crítica da relação entre sujeito e sociedade, para a qual o "Modernismo de 30" ou o "Ciclo de Romances do Nordeste" instituiu um olhar crítico ou de resistência. Pensar essa relação no regionalismo da década de 30 a partir da perspectiva de uma articulação com o dado real objetivo impõe que se considere a própria natureza da noção de representação no Modernismo brasileiro de 1922, levada a cabo a partir do diálogo com as vanguardas artísticas, desde Lasar Segall e Anita Malfatti ${ }^{9}$ até Oswald de Andrade e Murilo Mendes.

Tomando-se o movimento de renovação das artes brasileiras empreendido pelo Grupo de 22 como um eco dos desdobramentos da crise da representação ${ }^{10}$ que alimentara o desenvolvimento do trabalho artístico na Europa ao longo do século XIX, justifica-se a recusa de Mário de Andrade à prosa regionalista ao afirmar que o regionalismo não passava de uma "velha praga" na literatura brasileira - uma referência direta e irônica ao artigo publicado por Monteiro Lobato em 1917, no jornal O Estado de S. Paulo. Essa "necessidade de real" que determinara as formas do regionalismo desde suas primeiras realizações no Romantismo repete-se no século XX e se coloca, de modo consciente, como traço definidor desse tipo de ficção: "Preso à tradição e ao valor do documentário, ao regionalismo tem sido difícil aceitar a teoria de que o mundo da ficção vagos compromissos mantém com a realidade do contexto, do ambiente sócio-geográfico".

9 O processo de desvinculação entre linguagem pictórica e realidade ao longo dos anos que antecederam a Semana de Arte Moderna no Brasil é discutido por Sérgio Miceli sob um olhar que considera essa nova produção não como objeto isolado, mas no conjunto da sociedade da época, incluindo as interferências do mecenato e da elite na manutenção de um código menos academicista e mais abstrato, além da recepção das obras por esse público: "A repulsa enunciada por Lobato [em relação aos quadros de Anita Malfatti] incidiu, não por acaso, justamente naqueles trabalhos mais intrigantes, por conta do incômodo que deviam suscitar, derivado dessa confluência entre uma resolução plástica enfaticamente desestabilizadora, antimimética, e a pulsação de veios insólitos no tratamento desses figurantes embaraçosos, que eram os imigrantes". MICELI. Nacional estrangeiro, p. 111.

10 "Com a expressão de recente cunhagem crise de la représentation, descreve-se a experiência do fim do XVIII e começo do XIX de que os sistemas de representação humana, particularmente a linguagem, considerados suficientes na época clássica, já não se mostram adequados à realidade e que, desta maneira, o termo representação perde, enquanto forma de conhecimento, sua garantia universal relativa à ordem das coisas." BEHNKE. A crise da representação, p. 7.

11 ÉLIS. Tendências regionalistas no Modernismo, p. 96. 
O projeto ideológico do Modernismo de 30 permanece ligado ao Centro Regionalista do Nordeste, mas também se compromete com um projeto estético ${ }^{12}$ afinado ao desenvolvimento do romance como código de representação. Se essa articulação dá azo ao "realismo social da década de 30" em conta, também, que é justamente nesse ponto que se encontram, de um lado, uma observação aguda do real e, de outro, um modo de representação que coloca o "documentário" como constituinte de uma dimensão menos superficial do que aquela que, no Pré-Modernismo, incitou o comentário de Antonio Candido. Seja na linguagem de Graciliano Ramos, em Vidas secas, seja em Fogo morto, de José Lins do Rego, a heterogeneidade do "romance de 30" congrega em si um dado de fatura que o particulariza em relação ao regionalismo que antecedeu a Semana de 22.

A recuperação do lastro com o real não impede o romance regionalista de se desvencilhar do registro tipificador, ao contrário do que supunham os modernistas da primeira hora. O que entra em questão, nesse sentido, é o recorte da realidade que, desde o Romantismo, definiria essa literatura: o trabalho com regiões não hegemônicas do ponto de vista do desenvolvimento econômico e social, a tematização de espaços "outros" ou a representação de territórios que demarcam a desigualdade do processo de modernização brasileiro, que não se concretizou igualmente de norte a sul. A ideia de que o regionalismo é um retrato da sobrevida do subdesenvolvimento fomentaria a necessidade de escamoteação do dado local e faria desse lastro fundador algo a ser superado.

O posicionamento de Antonio Candido no ensaio "A nova narrativa" ${ }^{14}$ que define a produção de João Guimarães Rosa como caracterizadora de um "super-regionalismo", aponta para um olhar crítico que valida a narrativa rosiana justamente pelo que ela "supera" no regionalismo,

\section{Cf. LAFETÁ. 1930: a crítica e o Modernismo.}

13 SCHOLLHAMMER. À procura de um novo realismo. Teses sobre a realidade em texto e imagem hoje, p. 77.

14 Inicialmente com o título "O papel do Brasil na nova narrativa", o texto foi lido por Antonio Candido em 1979, em forma de comunicação, sendo publicado em 1981, na revista Novos Estudos CEBRAP. Sete anos após a publicação de "A literatura e a formação do homem”, o crítico não apenas mantém seu posicionamento inicial em relação ao texto regionalista como espaço em que a ficção permanece prenhe de real - e por isso seria um corolário do subdesenvolvimento, no caso da literatura brasileira - , como passa a assumir posição semelhante à de Machado de Assis com seu "Instinto de nacionalidade", já que a "superação" do regional garantiria a universalidade da literatura brasileira. 
[...] mostrando como é possível superar o realismo para intensificar o senso do real; como é possível entrar pelo fantástico e comunicar o mais legítimo sentimento do verdadeiro; como é possível instaurar a modernidade da escrita dentro da maior fidelidade à tradição da língua e à matriz da região. ${ }^{15}$

Não são poucos os trabalhos que, na última década, discutem o lugar ocupado pela realidade sertaneja na obra de Guimarães Rosa, compondo uma espécie de conjunto revisionista que chama a atenção para o fato de que o dado real não é superado ou amenizado na narrativa de Rosa e que, ao contrário, fazem-se presentes de modo orgânico as relações sociais e humanas definidas pelo sertão e sua economia geográfica e simbólica. Por outro lado, grande parte da crítica não somente decreta a morte do regionalismo a partir da produção rosiana, como também aplica, como critério de valoração, a ausência de vínculos com o dado regional, com a realidade local ou com elementos que façam referência a modos de vida distintos do real urbano. Essa postura chega à prosa contemporânea instituindo um domínio duplo, que envolve tanto a crítica quanto os autores ${ }^{16}$, tornando prementes questões como estas: como pensar a presença do dado regional na prosa contemporânea?; a representação do real, em narrativas que tratam de "territórios extremos" ", dá-se de maneira semelhante ao que definiu a narrativa de 30 ou, em outra direção, à produção de João Guimarães Rosa?

\section{Caminhos do sertão}

Sem insistir na dicotomia cidade versus campo a partir de um ponto de vista excludente ou meramente geográfico, é importante que se note que, a partir do final da década de oitenta do século XX, o espaço do sertão ou de regiões afastadas do eixo Rio-São Paulo retorna à ficção com força. Relato de um certo Oriente, publicado por Milton Hatoum em 1989, abre uma série de romances do autor centrados em uma Manaus histórica e, simultaneamente, imaginária,

15 CANDIDO. A nova narrativa, p. 207.

16 Em entrevista ao jornal O Estado de S. Paulo, Ronaldo Correia de Brito afirma que o termo regionalismo "não passa de palavrão" (GONÇALVES FILHO, 2005, p. 4).

17 PELEGRINI. Regiões, margens e fronteiras: Graciliano Ramos e Milton Hatoum, p. 117. 
mesclando os significados simbólicos do espaço à experiência individual de narradores à procura de identidade. Em 1991, Francisco J. C. Dantas publica Coivara da memória e fixa no solo do Nordeste a escrita de um tempo-espaço marcado pelo patriarcado, pelo poder local, pela reconstrução de ruínas que guardam o sentido da existência. Essa recuperação de um suposto "dado local" na ficção contemporânea marca, também, a tentativa de definição desse conjunto que, no interior de uma tendência essencialmente urbana, propõe a incorporação de um espaço outro.

A prosa de Ronaldo Correia de Brito coloca-se como elemento exemplar nessa discussão, que engloba não apenas a produção literária, mas os discursos que em torno dela se aglomeram. Faca, volume de contos publicado em 2003, delimita a soberania do sertão como espaço geográfico e simbólico de narrativas curtas, em cujo poder de síntese já se podiam antever observação aguda do real e interferência do mítico. Livro dos homens, de 2005, reitera realidade e mito no espaço do sertão, que agora se mostra entrecortado por uma dimensão contemporânea que altera o cotidiano sertanejo, mas também é alterada por ele. Enquanto a violência se firma como código de conduta e de honra onde o aparato governamental não chega completamente, o reisado, as procissões e rezas dividem espaço com a televisão e o rádio, formando um território híbrido.

É com o romance Galileia, publicado em 2008, que a representação do sertão na prosa de Ronaldo Correia de Brito ganha fôlego, desdobra-se e dá azo às discussões em torno da natureza regionalista - ou não - de sua narrativa. Abundam, nesse sentido, vozes que reiteram o fato de que o romance merece atenção por não ser representante de qualquer traço regionalista ou por, no limite, superar ou ultrapassar o dado regional: "Felizmente, passa longe do new regionalismo que tentam lhe atribuir: se finca no presente e permanece atento a uma realidade na qual, até segunda ordem, a globalização é soberana”. ${ }^{18}$ Subjaz a esse tipo de opinião a mesma postura que coloca o texto regionalista como tributário do subdesenvolvimento, o que seria, contemporaneamente, marca de atraso ou anacronismo e, portanto, motivo suficiente para que crítica e autor recusem qualquer ligação entre a obra e a tradição regionalista.

A partir do ponto de vista que norteia a discussão que aqui se vem fazendo, essa incorporação do sertão como realidade a ser representada interessa como observação do modo como o romance de Ronaldo Correia de

18 LANDO. Em "Galiléia", autor usa Bíblia para contar história no sertão, p. 1. 
Brito estabelece ligação - ou não - com o dado real na tessitura da narrativa. Galileia conta a trajetória de três primos que estão retornando à fazenda do avô, no interior do Ceará, para a festa de aniversário do patriarca da família, o que acaba se transformando em uma viagem fúnebre, já que, durante o percurso, chega a notícia de que Raimundo Caetano está em seu leito de morte. Toda a narrativa se estrutura a partir da voz de Adonias que, a bordo da caminhonete importada de Ismael e ao lado de Davi, irá dissecar os segredos da família e as relações de desejo, traição e morte guardadas em um baú empoeirado.

O romance se estrutura, portanto, a partir de dois signos distintos: de um lado, a travessia do sertão, na trajetória empreendida pelos primos de Recife aos Inhamuns; de outro, a casa da família, representada pela fazenda Galileia e seus diversos nichos, todos ligados às células familiares e suas dissidências. Como importante vetor da construção desses signos colocam-se a fala e a escrita de Adonias, já que ao mesmo tempo que narra, ele também se revela autor de um romance em processo de escritura. O movimento dos primos em direção à fazenda ocupa a metade da narrativa e deixa evidente a relação desse narrador com o sertão e com o tempo que ele representa: "Sinto fascínio e repulsa por esse mundo sertanejo. Acho que o traio, quando faço novas escolhas. Para o avô Raimundo Caetano somos um bando de fracos, fugimos em busca das cidades como as aves de arribação voam para a África". ${ }^{19}$

Em Adonias se situa, portanto, o eixo de representação da narrativa, e toda a subjetividade que daí se projeta determina a incorporação do dado real na tessitura do romance. Nesse sentido, o espaço percorrido ao longo da viagem à Galileia e os contornos da propriedade tomam forma a partir da vivência do personagem, que irá atribuir sentido ao trânsito e à estagnação de acordo com suas expectativas, frustrações e desejos. Importa observar nessa figura não apenas um filtro ideológico que se impõe à narração ${ }^{20}$, mas também a própria construção dos fatos pela experiência, aqui demarcada pela imagem da estrada e pela direção do trânsito, que aponta para o sertão e o tempo que ele guarda. Essa relação entre personagem e espaço, observada por Regina Dalcastagnè ${ }^{21}$ na

19 BRITO. Galileia, p. 16.

20 REIS; LOPES. Dicionário de teoria da narrativa, p. 251.

21 "Mais do que nunca, a personagem transporta seu próprio espaço. É em seu corpo que se inscrevem os lugares por onde andou, e aqueles que não lhe estão reservados." DALCASTAGNÈ. Violência, marginalidade e espaço na narrativa brasileira contemporânea, p. 72 . 
constituição de parte do romance brasileiro contemporâneo, aparece em Galileia como marca de um duplo movimento: o retorno ao sertão e à casa da infância, por um lado, o enfrentamento de recalques e a procura por uma identidade também em trânsito, por outro.

O motivo do trânsito e a figura da estrada compõem um dos cronotopos descritos por Bakhtin $^{22}$ (1998) na discussão das relações entre tempo e espaço na literatura, o que colocaria no cerne da composição do romance de Ronaldo Correia de Brito justamente o significado que se projeta de um espaço temporalizado pela experiência individual, qual seja a do próprio narrador. Cearense que nasceu na Galileia e optou por exercer a profissão de médico em Recife, Adonias inicialmente reluta em continuar na estrada que conduzirá à fazenda do avô, prevendo revelações ou a necessidade de enfrentamento de algo que não se conhece no princípio da narrativa. Nessa relutância estão depositados o passado e, também, o que dele resta no presente, em uma relação que faz do sertão o espaço detentor da experiência e da transformação. ${ }^{23}$

É no caminho que Adonias se depara com as transformações sofridas pelo sertão nas últimas décadas, traços suficientes para alterar os contornos do reconhecimento e da identificação. Incorporando elementos de modernização e, no limite, definidores da urbanidade e dos grandes centros, o sertão vê televisão e não tem mais seus vaqueiros. A rodovia substitui a velha estrada e transforma em velocidade o caminho percorrido pelos antepassados da família, que por ali transportaram um piano em direção à Galileia. A imagem do piano que é levado para o sertão como símbolo de requinte e modernidade faz referência direta ao piano de D. Amélia que, em Fogo morto, de José Lins do Rego ${ }^{24}$, agrega em si a síntese de dois tempos: de um lado, o auge do engenho Santa Fé, na metade do século XIX e, de outro, a falência provocada pela transformação nos meios de produção do açúcar e a tentativa de sobrevivência em meio ao caos.

22 Cf. BAKHTIN. Questões de literatura e de estética: a teoria do romance.

23 Observe-se que a centralidade do personagem como elo entre passado e presente na relação do sertão com o dado contemporâneo é um procedimento que se repete no conjunto da prosa do autor. No romance Estive lá fora, publicado em 2012, cabe ao jovem protagonista Cirilo, estudante de medicina em Recife, viver essa mesma cisão com o espaço e o tempo do sertão arcaico, já que, como o personagem de Galileia, também ele é descendente da família Rêgo Castro.

24 "E havia aquele piano. Era tudo o que o povo sabia. A sala de visitas tinha muito quadro, tinha um espelho para o corpo inteiro, tapetes no chão. O velho Lula não abria as janelas da sala de visitas; vivia ela fechada, com o piano de D. Amélia para um canto. E de que vivia aquele povo? As safras do Santa Fé não davam cem pães. Diziam que o velho ia todo ano ao Recife trocar moedas de ouro que o capitão Tomás deixara para a filha." REGO. Fogo morto, p. 26. 
Dois tempos também acompanham a rodovia que tem o sertão em suas margens; ocorre, porém, que a percepção dessa dualidade dá-se a partir do olhar de quem deixou o espaço e retorna em outro tempo. Sob esse aspecto, o caminho para Galileia deixa antever as duas pontas de um processo maior, que agora envolve as transformações ocorridas em fins do século XX e princípio do XXI. Nesse ponto, o romance traz a lume uma realidade outra, que se constituirá como diferente do sertão representado no romance de José Lins:

No posto rodoviário, um guarda federal espera a oportunidade de arrancar dinheiro de um motorista infrator. Mulher em motocicleta carrega uma velha na garupa e tange três vacas magras. Dois mitos se desfazem diante dos meus olhos, num só instante: o vaqueiro macho, encourado, e o cavalo das histórias de heróis, quando se puxavam bois pelo rabo. ${ }^{25}$

Essa realidade que chega ao romance via Adonias será incorporada em suas nuances mais fortes, sempre percebidas do ponto de vista das dissonâncias que a delimitam. É assim que ficam evidentes o contraste entre a lanchonete pobre de beira de estrada e o computador portátil de Davi, ou o disparate da atitude do filho do proprietário do local, que fora preso por roubar um aparelho celular que, naquele espaço, não recebia sinal e, portanto, não tinha serventia. Somados, esses contrastes levam à representação de um espaçotempo desigual, onde a globalização está, ao contrário do que afirma Vivien Lando, longe de ser soberana. A convivência - nem sempre harmônica - de dois tempos ressoa na articulação entre o moderno e os resquícios do arcaico, que se projetam na voz de Adonias como desdobramento de uma cisão na constituição do personagem.

Essa cisão pode ser compreendida quando se leva em conta o ponto de chegada do trânsito pelo sertão, qual seja a casa da propriedade que dá título ao romance. A figura da casa aparece imponente, como elemento determinante das imagens confusas que Adonias carrega consigo. Na Galileia, o narrador é obrigado a encarar aquilo que se esconde nos vãos da memória ou, no limite, o tempo retido nos alvéolos do espaço abandonado ${ }^{26}$ há muitos anos.

25 BRITO. Galileia, p. 8.

26 Em sua Poética do espaço, Gaston Bachelard aponta que a constituição da memória depende de uma impregnação do espaço pelo tempo, que guardaria as imagens do passado em fragmentos espaciais, compondo uma espécie de mosaico de pequenos sketches de estabilidade no fluxo temporal descontínuo do ser. 
Se a rodovia determina o espaço do trânsito, da mobilidade e da transformação, a fazenda fixa-se como ponto de conservação do passado, onde a estagnação insiste em se manter viva na figura moribunda do patriarca e na decadência de sua propriedade.

$\mathrm{Na}$ fazenda, portanto, Adonias encontra não apenas os restos materiais da época de apogeu da fazenda, mas também os escombros da própria família. À decadência da propriedade corresponde a falência moral dos indivíduos que a ocupam, de modo que a busca do narrador pelos segredos e interditos encontrará, na casa da Galileia, espaço cheio de lugares obscuros. Na relação de Adonias com a propriedade se desvela a segunda dimensão da narrativa, decalcada menos no solo do sertão e mais no domínio da experiência individual. Durante a convivência com os primos ao longo da viagem e no reencontro com a família, o narrador vê-se obrigado a mergulhar naquilo que não conhece de si mesmo: o desejo pelo primo Ismael, a repulsa por Davi - em quem descobre um gigolô de luxo que viajou a Europa como acompanhante de outros homens -, as relações extraconjugais do avô, o assassinato de Donana nas terras da fazenda.

Entra em cena, aqui, a autointertextualidade, que aparecerá, no romance, por meio da casa em que o assassino de Donana - o tio Domísio Justino - fora abrigado. Depois de uma briga em que atingira o primo Ismael com uma pedra, Adonias pede ao tio para visitar o quarto em que Domísio se escondera e, em seu interior, enfrenta a presença fantasmagórica do assassino da família, capaz de revelar a ele, Adonias, todo o potencial vingativo que fazia parte de seu sangue e de sua história:

- [...] Hoje à tarde, você atraiu Ismael para o mesmo lugar em que eu matei Donana. Você já cansou de ouvir essa história. Tanto que já nem sabe se ela é minha ou sua. Além de repetir o meu crime, como se não bastasse a semelhança, correu para a mesma casa, e procurou se ocultar no quarto em que me escondo. ${ }^{27}$

A voz de Domísio soa como alucinação para o leitor que, conhecedor de "Faca" ${ }^{28}$ "O que veio de longe", torna-se capaz de perceber a ironia que também condena o narrador em seu suposto crime. É justamente

27 BRITO. Galileia, p. 151.

28 Cf. BRITO. Faca. In: Faca, p. 22-33.

29 Cf. BRITO. O que veio de longe. In: Livro dos homens, p. 6-14. 
essa ironia que põe em cena o fato de que o crime cometido por Adonias não é necessariamente a agressão a Ismael, mas o retorno a um território que não lhe pertence. O enfrentamento do passado coloca Adonias diante de si mesmo enquanto sujeito que não se encaixa naquele espaço e, ao mesmo tempo, não se reconhece em qualquer espaço outro. A fala do personagem é, portanto, a reconstrução de um caminho de retorno, e o desvendamento do ponto de chegada se faz impossível na medida em que o espaço do sertão guarda o silêncio de uma experiência que não pode ser recomposta. Sob esse aspecto, o narrador do romance funciona como meio de representação de dois tempos inconciliáveis, ambos colocados na narrativa: o passado e o presente, que configuram as transformações no sertão e a cisão da própria vida:

Vago numa terra de ninguém, um espaço mal definido entre campo e cidade. Possuo referências do sertão, mas não sobreviveria muito tempo por aqui. Criei-me na cidade, mas também não aprendi a ginga nem o sotaque urbanos. Aqui ou lá me sinto estrangeiro. ${ }^{30}$

A narrativa contempla apenas parte da viagem de volta de Adonias para Recife e não chega a mencionar sua chegada à capital, o que mantém esse embaralhamento de espaços no interior do personagem, que permanecerá a meio caminho da cidade e do sertão. Essa posição intersticial - definida tanto espacial quanto temporalmente - auxilia no modo como o sertão é representado pela narrativa e se projeta também em sua concepção como matéria literária, já que o romance não deixa de tematizar a escrita do sertão por meio da fala de Adonias.

\section{Considerações finais}

Galileia incorpora em sua tessitura uma discussão metaliterária em torno da prosa regionalista brasileira e de sua permanência - ou não - na literatura contemporânea, o que acontece ao longo de todo o romance, seja pela relação dos personagens com o espaço do sertão, seja pela figura do livro que está sendo escrito por Adonias. Embora não apareça em nenhum momento da narrativa, esse livro e as reflexões do personagem em torno da natureza da ficção inserem o romance de Ronaldo Correia de Brito em uma problemática

30 BRITO. Galileia, p. 160. 
mais ampla, que se refere à possibilidade de reinvenção do romance regionalista e à condenação da permanência de modos supostamente anacrônicos de representação.

Adonias coloca-se como o escritor que recusa a ideia de que o regionalismo possa ser tomado como forma passível de valoração no conjunto da prosa contemporânea, partindo do princípio de que o autor regionalista seria, hoje, a manutenção de uma literatura calcada no subdesenvolvimento e na desigualdade. O contraponto à postura do escritor supostamente cosmopolita representado por Adonias é seu tio Salomão, estudioso da cultura popular e proprietário de uma vasta biblioteca em que o erudito e o tradicional convivem lado a lado. A dissonância entre essas duas vozes se evidencia no diálogo que se estabelece entre ambos e, sobretudo, nas reflexões de Adonias sobre a figura do tio: "- Tio Salomão é um regionalista. Existe coisa mais fora de moda do que um regionalista?"

Estar fora de moda significa, nesse caso, assumir uma posição descompassada em relação ao restante da literatura produzida contemporaneamente, ou seja, o tio Salomão, assim como a fazenda Galileia, estariam estagnados e não teriam acompanhado o progresso. É, contudo, no posicionamento defendido pelo próprio Salomão que se coloca um olhar bastante peculiar em relação ao conceito de regionalismo: o pensamento de Salomão evidencia uma recusa que se projeta em relação ao paradigma proposto pelo Grupo Regionalista do Nordeste, sobretudo quando se considera que o projeto do grupo tinha como um de seus objetivos a revitalização da cultura nordestina, valorizando o dado regional peculiar, por meio de sua incorporação na forma narrativa. ${ }^{32}$ É justamente na particularização e na tipificação que se encontram, também, a rechaça de Adonias e a sua proposta de criação de um projeto literário que, embora se mostre oposto a qualquer possibilidade de categorização como regionalista, não chega a se evidenciar ao longo do romance Galileia.

Há que se considerar que o papel desempenhado por Adonias encontra correspondente na própria figura de Ronaldo Correia de Brito, que se posiciona negativamente em relação ao regionalismo e à possibilidade de inserção de Galileia em um paradigma regionalista de representação. Ocorre, no entanto, que a tematização da escrita regionalista por dois personagens no romance torna importante o fato de que a própria narrativa pode ser pensada a partir de

31 BRITO. Galileia, p. 163.

32 Cf. FREYRE. Manifesto regionalista de 1926. 
uma perspectiva que a tome como existência de uma atualização do romance regionalista na ficção brasileira. Soma-se a isso o fato de que, sem o reducionismo de parte da crítica, que toma o espaço do sertão como elemento que determina a natureza regionalista do texto, Galileia coloca-se como uma narrativa que representa as dimensões sociológica, simbólica e humana de um espaço que permanece, ainda contemporaneamente, com particularidades em relação a um território tido como central ou economicamente hegemônico.

Enquanto Milton Hatoum faz de Manaus um espaço literário modificado pela memória e pela experiência de seus personagens, o sertão aparece em Galileia como território da mesma natureza, aqui demarcado pelo reencontro, pelo trânsito e pela procura da identidade..$^{33}$ Nessa criação de um espaço vivido coloca-se a necessidade de real que move o romance regionalista desde sua formação, no Romantismo. Em Galileia, o dado real chega na narrativa concentrando as dissonâncias de um sertão que mescla o contemporâneo do rádio, da televisão e das motocicletas ao arcaico dos costumes dos vaqueiros, das rezadeiras e de um código de honra cuja vigência se mantém paralelamente ao aparato governamental. A junção de elementos dissonantes marca o dado real, mas também define a identidade do personagem que, assim como o próprio sertão, busca conciliar diferentes tempos em si mesmo.

Em tom menos documentário do que aquele observado por Antonio Candido na literatura regionalista de princípios do século $\mathrm{XX}^{34}$, a realidade sertaneja que se impõe à narrativa de Ronaldo Correia de Brito, na primeira década do século XXI, exige a discussão em torno da existência de um novo romance regionalista ou, se mais adequado, de uma prosa regionalista erigida a partir de outros modos de representação. É assim que a realidade sertaneja contemporânea - marcadamente característica da constituição socioeconômica brasileira - entranha-se à narrativa como experiência identitária de um sujeito que, no texto, olha para essa realidade e a elabora como traço constitutivo de sua própria condição no mundo, o que faz com que o que poderia ser tomado como um espaço do outro seja, no limite, o lugar de si mesmo.

33 "São como territórios concêntricos, um dentro do outro: a Manaus real e seu duplo, a Manaus imaginária; dentro, a colônia libanesa, no centro da qual as casas das famílias avultam como espaço privilegiado." PELLEGRINI. Milton Hatoum e o regionalismo revisitado, p. 128.

34 Cf. CANDIDO. A literatura e a formação do homem. 


\title{
Reality and representation in Brazilian regionalist novel: the tradition and the present
}

\begin{abstract}
This work presents a discussion on Brazilian regionalist novel and its relationship to representation of reality along of Brazilian history of literature. Under this point of view, this article analyzes how the novel Galileia, by Ronaldo Correia de Brito, retakes, refuses or brings up to date, in contemporary prose, some aspects that established this kind of production inside literary diachrony in Brazil.
\end{abstract}

Keywords: Regionalist novel, Representation, Contemporary narrative.

$$
\text { Referências }
$$

ASSIS, M. de. Obras completas. São Paulo: Gráfica Editora Brasileira, 1955. v. III.

BACHELARD, G. A poética do espaço. São Paulo: Martins Fontes, 2000.

BAKHTIN, M. Questões de literatura e de estética: a teoria do romance. 4 ed. São Paulo: Editora UNESP; Hucitec, 1998.

BEHNKE, K. A crise da representação. In: BEHNKE, K.; FABBRI, P.; LIMA, L. C. Crises da representação. Rio de Janeiro: Universidade do Estado do Rio de Janeiro, 1994. p. 7-24. [Cadernos do Mestrado/Literatura.]

BRITO, R. C. de. Estive lá fora. Rio de Janeiro: Objetiva, 2012.

BRITO, R. C. de. Faca. São Paulo: Cosac Naify, 2003.

BRITO, R. C. de. Galileia. Rio de Janeiro: Objetiva, 2008.

BRITO, R. C. de. Livro dos homens. São Paulo: Cosac Naify, 2005.

CANDIDO, A. A literatura e a formação do homem. Ciência e cultura, São Paulo, v. 24, n. 9, p. 802-803, 1972.

CANDIDO, A. A nova narrativa. In: A educação pela noite e outros ensaios. 3 ed. São Paulo: Ática, 2000. p. 199-215.

CANDIDO, A. Literatura e subdesenvolvimento. In: A educação pela noite e outros ensaios. 3 ed. São Paulo: Ática, 2000. p. 140-162.

DALCASTAGNÈ, R. Violência, marginalidade e espaço na narrativa brasileira contemporânea. Diálogos Latinoamericanos, México, n. 11, p. 72-82, 2006.

ÉLIS, B. Tendências regionalistas no Modernismo. In: ÁVILA, A. O Modernismo. São Paulo: Perspectiva, 1975. p. 87-102.

FREYRE, G. Manifesto regionalista de 1926. Departamento de Imprensa Nacional; Serviço de Educação, 1955.

GONÇALVES FILHO, A. O sertão quer deixar de ser sertão. O Estado de S. Paulo, São Paulo, 08 jul. 2005. Caderno 2, p. 4.

LAFETÁ, J. L. 1930: a crítica e o modernismo. 2 ed. São Paulo: Duas Cidades; Ed. 34, 2000. 
LANDO, V. Em "Galiléia", autor usa Bíblia para contar história no sertão. Folha de S.Paulo. São Paulo, 29 nov. 2008. Ilustrada, p. 1.

MARCHEZAN, L. G. Introdução. In: MARCHEZAN, L. G. (Org.) O conto regionalista: do romantismo ao pré-modernismo. São Paulo: Martins Fontes, 2009. p. ix-lvi.

MICELI, S. Nacional estrangeiro: história social e cultural do modernismo artístico em São Paulo. São Paulo: Companhia das Letras, 2003.

PELLEGRINI, T. Milton Hatoum e o regionalismo revisitado. Luso-Brazilian Review, Wisconsin, v. 41, n. 1, p. 121-138, 2004.

PELLEGRINI, T. Realismo: postura e método. Letras de hoje, Porto Alegre, v. 42, n. 4 , p. 137-155, dez. 2007.

PELLEGRINI, T. Regiões, margens e fronteiras: Graciliano Ramos e Milton Hatoum. In: Despropósitos: estudos de ficção brasileira contemporânea. São Paulo: Annablume; FAPESP, 2008. p. 117-136.

REGO, J. L. do. Fogo morto. 47 ed. Rio de Janeiro: José Olympio, 1997.

REIS, C.; LOPES. A. C. M. Dicionário de teoria da narrativa. São Paulo: Ática, 1988.

SANTIAGO, S. A permanência do discurso da tradição no modernismo. In: Nas malhas da letra. Rio de Janeiro: Rocco, 2002. p. 108-144.

SCHOLLHAMMER, K. E. À procura de um novo realismo. Teses sobre a realidade em texto e imagem hoje. In: SCHOLLHAMMER, K. E.; OLINTO, H. K. (Orgs.). Literatura e cultura. Rio de Janeiro: PUC-Rio; São Paulo: Loyola, 2003. p. 76-90.

TÁVORA, F. O cabeleira. Rio de Janeiro: Ediouro, 1969. 
